\title{
Ultrasound-assisted Emulsified Microextraction Followed by High Performance Liquid Chromatography for Permethrin
}

\author{
Mehran Pourhossein ${ }^{a, b}$, Alireza Golaghaei*a, \\ Ramin Khaghani ${ }^{\mathrm{a}}$ and Babak Paknezhad ${ }^{\mathrm{a}}$ \\ ${ }^{a}$ AJA University of Medical Sciences \\ Tehran, Iran \\ ${ }^{b}$ Tehran University of Medical Sciences \\ Tehran, Iran
}

Received 26.08.2021, received in revised form 29.09.2021, accepted 25.10.2021

\begin{abstract}
Ultrasound assisted emulsification microextraction (UAEME) as a new sample preparation method was optimized for the determination of permethrin in urine samples. Also, deep eutectic solvent was used as the extracting solvent instead of organic solvents in this method. In order to determine the optimal values, six main parameters were studied in different levels. Totally, 105 runs were performed using the one-variable-at-a-time method followed by high-performance liquid chromatography with a UV detector. Under the optimum conditions, the calibration curve for permethrin was linear in the concentration range of 5 to $500 \mu \mathrm{gL}^{-1}$ for urine samples. The accuracy and reproducibility of the introduced method were determined using the relative recovery (RR\%) and relative standard deviation (RSD\%) tests on the fortified urine samples. RR\% and RSD\% were found to be $96.3-101.7 \%$ and $3.2-7.6 \%$, respectively. The limit of quantification and also the limit of detection were obtained 5 and 1 $\mu \mathrm{g} / \mathrm{L}$, respectively. In the present study, the DES-UA-EME technique was successfully developed for the extraction of permethrin from urine samples and subsequent quantification by high-performance liquid chromatography.In comparison to the other sample preparation methods, the proposed technique has the advantages of shorter extraction time, simplicity, and applicability in laboratories with less equipment.
\end{abstract}

Keywords: deep eutectic solvents, sample preparation, ultrasound assisted emulsified microextraction, permethrin, high performance liquid chromatography.

Acknowledgements. The authors acknowledge the AJA University of Medical Sciences and also the laboratory personnel for all valuable supports.

(C) Siberian Federal University. All rights reserved

This work is licensed under a Creative Commons Attribution-NonCommercial 4.0 International License (CC BY-NC 4.0).

* Corresponding author E-mail address: golaghaei.md@gmail.com 


\title{
Эмульгированная микроэкстракция \\ с помощью ультразвука с последующей высокоэффективной жидкостной хроматографией для перметрина
}

\author{
Мехран Пурхоссейна ${ }^{\mathrm{a}, \tilde{\sigma}}$, Алиреза Голагай ${ }^{\mathrm{a}}$, \\ Рамин Хагани ${ }^{\text {a }}$ Бабак Пакнежад ${ }^{\mathrm{a}}$ \\ ${ }^{a}$ Медииинский университет Армии Исламской Республики Иран \\ Тегеран, Иран \\ ${ }^{6}$ Тегеранский медицинский университет \\ Тегеран, Иран
}

\begin{abstract}
Аннотация. Микроэкстракция эмульгирования с помощью ультразвука в качестве нового метода подготовки образцов была оптимизирована для определения перметрина в образцах мочи. Кроме того, в этом методе в качестве экстрагирующего растворителя вместо органических растворителей использовался глубокий эвтектический растворитель. Для определения оптимальных значений были изучены шесть основных параметров на разных уровнях. Всего было выполнено 105 прогонов с помощью метода одной переменной, за которыми последовала высокоэффективная жидкостная хроматография с УФ-детектором. В оптимальных условиях калибровочная кривая для перметрина была линейной в диапазоне концентраций от 5

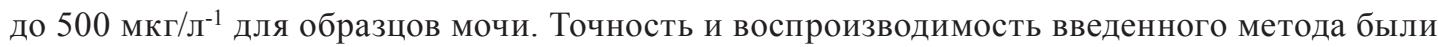
определены с использованием тестов относительного восстановления (ОВ\%) и относительного стандартного отклонения (ОСО\%) на обогащенных образцах мочи. ОВ\% и ОСО \% составили 96,3-101,7 \% и 3,2-7,6 \% соответственно. Пределы количественных показателей обнаружения 5 и 1 мкг/л соответственно. В настоящем исследовании была успешно разработана методика микроэкстракции эмульгирования с помощью ультразвука для извлечения перметрина из образцов мочи и последующего количественного определения с помощью высокоэффективной жидкостной хроматографии. По сравнению с другими методами подготовки образцов предложенный метод обладает такими преимуществами, как более короткое время экстракции, простота и возможность применения в лабораториях с меньшим количеством оборудования.
\end{abstract}

Ключевые слова: глубокий эвтектический растворитель, подготовка образцов, микроэкстракция эмульгирования с помощью ультразвука, перметрин, высокоэффективная жидкостная хроматография.

Благодарности. Авторы выражают признательность Университету медицинских наук АЯ, а также персоналу лаборатории за всю ценную поддержку. 
Цитирование: Мехран, Пурхоссейн. Эмульгированная микроэкстракция с помощью ультразвука с последующей высокоэффективной жидкостной хроматографией для перметрина / Пурхоссейн Мехран, Голагай Алиреза, Хагани Рамин, Пакнежад Бабак // Журн. Сиб. федер. ун-та. Химия, 2021, 14(4). C. 447-446. DOI: 10.17516/1998-2836-0253

\section{Introduction}

Pesticides are a group of chemical substances extensively used to eliminate, keeping away, or removing any kind of insect, rodent, fungi, or other types of annoying organisms. Although pesticides have a great impact on improving agricultural productivity and increase of food production, the processes of production, formulation, storage, transformation, and marketing of crops and also the wide application of these substances cause occupational exposures, environmental contamination, and the presence of their residuals in food [1]. Small amount of pesticides can also cause the occurrence of symptoms, diseases, and irreparable poisonings in humans. Thus, trace monitoring of these compounds is of great importance from occupational and environmental perspectives [2].

Permethrin isan insecticide in the pyrethroid family used to eradicate parasites such as head lice, ticks and scabies from humans and animals [3]. Permethrin affects the neuronal membrane by blocking the movement of sodium ions from outside to inside the neuronal cell membrane thereby disrupting the sodium channel current that regulates the polarization of the membrane. This leads to delayed repolarization and subsequent paralysis of the nervous system [4]. Human and animal studies have shown evidence of a relationship between exposure to this pesticide and genotoxic effects, cellular changes, and the occurrence of some disorders in the immune system, liver, kidney, and thyroid [5].

Considering the extensive use of pesticides, development of fast and reliable technique for trace residue analysis of these compounds in various media such as biological, food, fruit, and vegetable samples is of great importance [6]. Among the instrumental methods, high-performance liquid chromatography (HPLC) instrument is an appropriate option for analyzing trace amount of pesticides in different samples, such as water, urine, and fruits [7].

Sample preparation is considered an important step in the process of analysis. The main goals of sample preparation are elimination of interfering agents, preconcentration of the desired analyte, and transforming the analyte (if required) to a more appropriate extraction solvent. In addition, using smaller sample volume, improvement of selectivity in the extraction process, automation, reducing the consumption of organic solvents and laboratoryequipment have been proposed recently [8].

In the past, two methods of liquid-liquid extraction [9] and solid-phase extraction [10], were often used for extraction and pre-concentration of analytes from the sample matrices. Recently, novel procedures, in which, low amount of organic solvents are used, have been developed. For example, in the liquid phase microextraction (LPME) method, the extraction of analyte from a sample containing the liquid phase is performed using small amount of water-insoluble solvent [11]. The LPME technique is divided into three main categories including single-drop microextraction (SDME), hollow fiber liquid-phase microextraction (HF-LPME), and dispersive liquid-liquid microextraction (DLLME) [12].

In 2006, DLLME method was introduced by Rezaei et al. The DLLME method is applicable for a variety of samples such as soil, urine, and food. In this procedure the extraction process is based on the tendency of the analyte to the aquatic sample phase and the organic phase of the extractor solvent

$$
-449-
$$


[13]. Considering the advantages of the relatively novel DLLME method over the previous methods, its attraction has been retained for the analytical toxicologists, and, in comparison with the other sample preparation techniques, it has a significant share of studies. However, DLLME suffers from some limitations. The first and most important drawback is the application of an extra organic solvent as a disperser solvent, which causes entrance of the added solvent into the environment. Also, the required time of preparation is extended due to the numerous steps during the sample preparation process. Although by manual injection of the extractor solvent into the sample, the tiny droplets and cloudy phase are rapidly created, the contact surface between the aqueous phase of the sample solution and the organic phase of the extractor solvent is not in its maximum range [14].

In addition to the benefits that the DLLME method poses, the ultrasound-assisted emulsified microextraction (UA-EME) technique has other advantages such as the ease of forming small emulsions, creating the maximum contact surface between the aqueous phase of the sample and the organic phase of the extractor solvent. Moreover, ultrasound application liminated is perser solvent consuming and avoids increasing the sample and wastewater volumes [15].

The only limitation of this technique is using organic solvents as the extractor solvent. The organic halogenated solvents, especially chlorinated solvents (e. g. carbon tetrachloride, etc.), which are usually used as the extractor solvent, have some disadvantages such as toxicity, incompatibility with the environment, and high price [16]. In order to eliminate this limitation, which can be considered as the last remaining limitation for solvent-based microextraction methods, development of a novel extraction method using environment friendly extraction solvent is essential.

DES is produced by combining two natural substances, between which the hydrogen bond forms during synthesize process. The substance with free electron pairs is known as hydrogen bonding donor (HBD) and the substance with empty orbit is known as hydrogen bond acceptor (HBA).One or both raw materials may be solid, however the resulting product of such combination has a liquid form and much lower melting point comparing to the initial substances [17]. In comparison to the other solvents, the DESs have advantages such as more compatibility to the environment as well as biodegradability, nontoxicity, and also it is more inexpensive. Moreover, the physicochemical properties of the DESs, such as density, viscosity, conductivity, surface tension, and etc., can be engineered and changed as needed [18]. Thus, with the assessment of the feasibility of applying DESs instead of organic solvents in sample preparation methods, it would be possible to reach a novel method.

The aim of this study was the development of DES-UAEME method as a rapid, easy, inexpensive, effective, safe, and environment friendly sample preparation procedure for determination of trace permethrin in urine samples, in which, the substitution of chlorinated organic solvents (COSs) with DESs is considered to eliminate the drawbacks of previous sample preparation methods.

\section{Methods}

\section{Chemicals}

Permethrin standard was obtained from Sigma-Aldrich (Germany). The analytical grade of organic solvents, including chlorobenzene, carbon tetrachloride, chloroform, methanol, and acetonitrile, were purchased from Merck (Germany). Also, chemical substances of choline chloride, Urea, sodium chloride, tetrahydrofuran (THF) with the purity of higher than $99 \%$, and buffer solutions at different $\mathrm{pH}$ were bought from Merck (Germany). 


\section{Instruments}

In order to analyze the samples, a high-performance liquid chromatography system, equipped with a K-1001 pump and a K-2006 ultraviolet detector (Knauer, Germany), was used. The chromatography conditions were a $\mathrm{C} 18$ column ( $\mathrm{L}=150 \mathrm{~mm}, \mathrm{ID}=4.6 \mathrm{~mm})$, a mobile phase of methanol $(70 \%)$, and water (30\%), pump flow-rate of $1.0 \mathrm{ml} / \mathrm{min}$, column temperature of $25^{\circ} \mathrm{C}$, and ultraviolet wavelength $290 \mathrm{~nm}$, respectively. The other equipment and tools used in this study include a double ionized water distillation machine (PURITE, USA), micro sampler (Socorex, Germany), digital scale (Sartorius, Germany), ultrasonic bath (Sono, Switzerland), magnetic stirrer (Chiltern, USA), digital thermometer (TP3001, China), pH meter (Metrohm, Switzerland), centrifuge (Hettich zentrifugen Rotofix 32, China).

\section{Preparation of stock and standard solutions}

The stock solution with the concentration of $1000 \mathrm{mg} / \mathrm{L}$ was prepared in acetonitrile and kept in the refrigerator at $4{ }^{\circ} \mathrm{C}$. The standard solutions with different concentrations were prepared daily by diluting the stock solution with deionized water.

\section{Synthesis of DES}

In order to synthesis DES, choline chloride as the HBA, and urea as the HBD were combined in the specified molar ratios at $50^{\circ} \mathrm{C}$ for $5 \mathrm{~min}$, to obtain three hydrophobic DES with different structures. Considering the addition of urea molar ratio in preparation of DES, the viscosity of the DES solution can be decreased. In this way, the solution with the ratio of 1:1 has the highest viscosity and the solution with the ratio of 1:4 has the lowest viscosity, so that the solution with the ratio of 1:1 has a very high viscosity, Therefore, the ratios of 1:2 (DES1), 1:3 (DES2), and 1:4 (DES3) were selected for the investigation.

\section{Ultrasound-assisted emulsification microextraction}

a) $300 \mu \mathrm{L}$ of the extraction solvent (DES1) was injected through a syringe into a $15 \mathrm{~mL}$ sample tube containing $10 \mathrm{~mL}$ of sample. b) Then, $300 \mu \mathrm{L}$ of THF as an emulsifier agent was injected into the solution and at this stage a cloudy solution, which prove the formation of insoluble self-aggregation in nano and molecular dimensions was formed. The cloudy solution was subjected to ultrasonication to guarantee well distribution of extraction solvent droplets in aqueous phase. c) In the next step, the solution was centrifuged and two separated phases were obtained. The phase containing the analyte was separated using a syringe and poured into a new tube and was dried under a nitrogen stream. d) Finally, the residual substance was dissolved in acetonitrile and was injected to HPLC-UV for quantification.

\section{Optimization procedure}

In order to determine the optimal values and levels of the effective factors in the extraction of permethrin via UA-EME method, six effective parameters including the type of extraction solvent, extraction solvent volume, the amount of added salt, sample $\mathrm{pH}$, time of exposure with ultrasonic (sonication time), and centrifugation time were selected. The design of experiments was performed using the one-variable-at-a-time method, and each parameter was tested in different levels and three 
Table 1. The variables and levels in the optimization steps

\begin{tabular}{|l|c|c|c|c|c|c|}
\hline \multicolumn{1}{|c|}{ Variables } & \multicolumn{5}{c|}{ Levels } \\
\hline Type of extraction solvent & Chlorobenzene & $\begin{array}{c}\text { Carbon } \\
\text { tetrachloride }\end{array}$ & Chloroform & DES1 & DES2 & DES3 \\
\hline Extraction solvent volume $(\boldsymbol{\mu L})$ & 100 & 200 & 300 & 400 & 500 & 600 \\
\hline The amount of added salt $(\mathbf{W} / \mathbf{\%} \%)$ & 0 & 5 & 10 & 15 & 20 & 25 \\
\hline Sample pH & 3 & 5 & 7 & 9 & 11 & - \\
\hline Sonication time(min) & 5 & 10 & 15 & 20 & 25 & 30 \\
\hline Centrifugation time(min) & 2 & 4 & 6 & 8 & 10 & 12 \\
\hline
\end{tabular}

replicates to select the optimal values. In each step of optimization, all the effective variables are kept constant except the desired parameter which is changed in different levels of the experimental range to determine its optimal value. The experiment steps were done with three replicates and the average values were reported as results. Totally, 105 steps were performed for optimization of the effective factors in the extraction of permethrin from standard samples. Table 1 shows the variables with corresponding levels in the optimization steps.

\section{Results and discussion}

\section{Selection of the extraction solvent}

In the UA-EME process, the extraction solvent must have certain properties such as insolubility in water, and the ability to extract the desired compound as well as the appropriate chromatographic behavior. In order to develop the application of DES in the mentioned method, three solvents, DES1, DES2, and DES3 which their compositions were described in the previous section were tested in addition to three mentioned organic solvents including chlorobenzene $\left(\mathrm{C}_{6} \mathrm{H}_{5} \mathrm{Cl}\right)$, carbon tetrachloride $\left(\mathrm{CCl}_{4}\right)$, and chloroform $\left(\mathrm{CHCI}_{3}\right)$.Therefore, 6 parallel levels were examined.

Based on the obtained results, during the application of chlorobenzene and chloroform as the extraction solvent, after the formation of the cloudy phase and in the step of separating the extraction solvent through the centrifuge, the whole volume of the added extraction solvent has not separated which could be due to their small amount of solubility in water. This issue reduced the extraction ability of these solvents in comparison to the other solvents. Overall, among the six studied extraction solvents, DES1 and carbon tetrachloride showed the highest relative recovery (RR), however, due to the advantages of DES compared to the organic solvents, DES1 was selected as the optimum extraction solvent for the next steps (Fig. 1a).

\section{Selecting the volume of extraction solvent}

In this step, to investigate the effect of extraction solvent volume on the analyte extraction recovery, the experiments were performed using various volumes in 6 parallel levels ranged from 100 to $600 \mu \mathrm{L}$ of DES1. The lower range of extractant solvents volume was considered to be $100 \mu \mathrm{L}$, equivalent to HPLC injection volume. On the other side, due to the dilution effect, applying a high volume of extraction solvent cause a decrease in the enrichment factor. To prevent this, the upper level of the extracting solvent was considered to be $600 \mu \mathrm{L}$. The maximum recovery was 
(a)

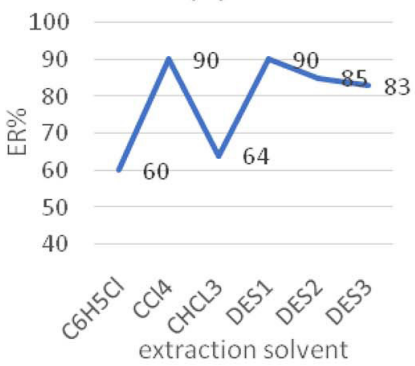

(d)

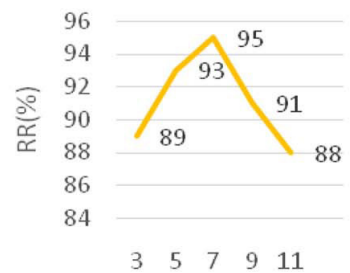

$\mathrm{pH}$ (b)

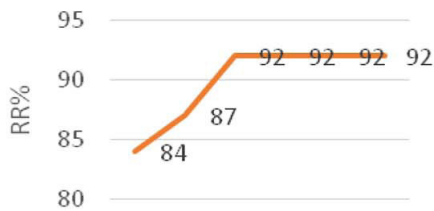

100200300400500600

extrection solvent volume(

(e)

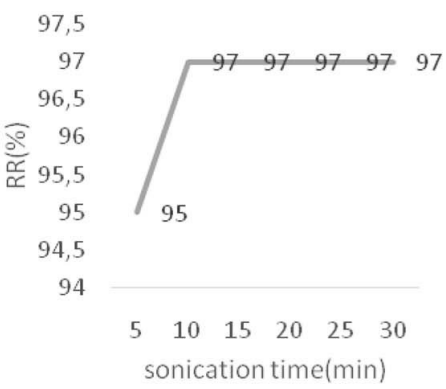

(c)

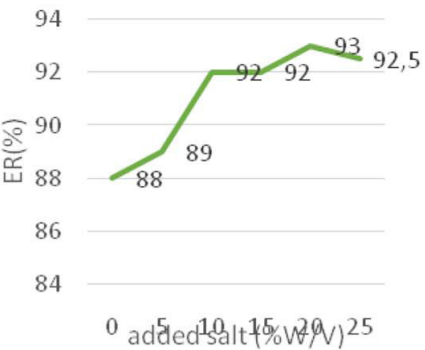

(f)

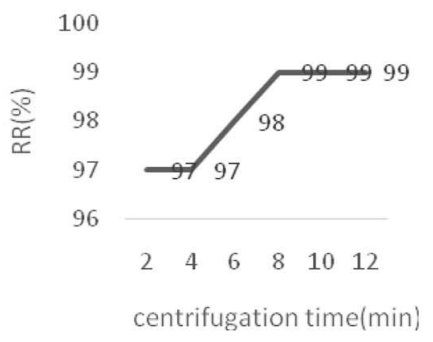

Fig. 1 Steps to optimize the factors affecting extraction: a selection of the extraction solvent type; $\mathbf{b}$ selecting the volume of extraction solvent; $\mathbf{c}$ the effect of salt addition; $\mathbf{d}$ effect of sample $\mathrm{pH}$; e effect of sonication time; f Effect of centrifugation time

obtained when $300 \mu \mathrm{L}$ of DES1 was employed as extracting solvent. In the higher solvent values, the recovery rate remained constant, therefore, a volume of $300 \mu \mathrm{L}$ was selected as optimum value (Fig. 1b).

\section{The effect of salt addition}

Due to the fact that ionic compounds have the highest solubility in water, the addition of salt to the solvent facilitates the analyte removal from the aqueous sample. This variable is called ionic power. In order to study the effect of adding salt, six different values of sodium chloride in the range of $0-25 \mathrm{~W} / \mathrm{V} \%$ were applied.

The obtained results showed that, by the increase of salt concentration, the extraction rate diminishes, and the highest analyte extraction rate was obtained when no salt was added to the sample. It is because of the increase in sample viscosity that caused a reduction in the analyte penetration coefficient. Therefore, $0 \%$ was selected as the optimum value and the next steps of the optimization were carried out without the salt addition (Fig. 1c).

\section{The effect of sample $\mathrm{pH}$}

Through the adjustment of $\mathrm{pH}$, the analyte molecules could be directed towards the ionization or molecular forms. In order to easier extraction of the analyte from aqueous samples (water-based samples such as biological samples), it must be directed towards molecularization. With the addition of an appropriate amount of hydrochloric acid or sodium hydroxide to the sample, permethrin extraction rate was studied. For this purpose, the $\mathrm{pH}$ of the sample was examined at 5 levels in the range of 3-11. 
The highest extraction rate was achieved in around $\mathrm{pH}=7$. Thus, the $\mathrm{pH}$ value of 6 was chosen for the next steps (Fig. 1d).

\section{Effect of sonication time}

In the sonication step, the test tube containing the sample and extraction solvent was placed in the ultrasonic bath to achieve maximum contact between the extraction solvent and sample solution. The effect of sonication time on the extraction efficiency was investigated in the 6 levels ranged 5-30 minutes. After 10 minutes, the extraction efficiency was constant. Therefore, 10 minutes was selected as the optimal sonication time for the next steps of the experiment (Fig. le).

\section{Effect of centrifugation time}

The centrifugation time in the UA-EME method is an important step to separate the extraction solvent from the sample. During this step, the cloudy phase of the sample disappears and two separate and clear phases are created. The effect of centrifuge time and speed on the extraction efficiency was investigated at 6 levels of the time ranges from 2-12 minutes using speed of 2500-4000 rpm. After 8 mins, the extraction efficiency was constant and the maximum extraction efficiency was obtained at the speed of $4000 \mathrm{rpm}$. Thus, the time of 8 minutes and the speed of $4000 \mathrm{rpm}$ were chosen as the optimum values for the next steps (Fig. If).

\section{Analytical performance}

In order to draw the calibration curve, blank urine samples of unexposed individuals were diluted at a ratio of 1:2 in deionized water and then spiked with certain concentrations. Then, the prepared samples were extracted via the developed preparation method. The sketched calibration curve was linear in the concentration range of 5 to $500 \mu \mathrm{g} / \mathrm{L}(\mathrm{n}=5)$ and desirable linearity $\left(\mathrm{R}^{2}=0.999\right)$ was achieved. The limit of quantification (LOQ), based on the lowest detected analyte concentration with $85-115 \%$ accuracy and precision $\leq 10 \%$ in five consecutive injections, and also the limit of detection (LOD, signal/noise $=3$ ) were obtained 5 and $1 \mu \mathrm{g} / \mathrm{L}$, respectively. The analytical figures achieved for the developed technique confirmed the proper efficiency, linearity, and reproducibility of this process for the quantification of permethrin in urine samples.

\section{Application assay}

In order to assess the applicability and efficiency of the developed DES-USAEME method for the real urine samples, the spiked urine samples of unexposed persons with standard permethrin concentrations of 5,50, and $150 \mu \mathrm{g} / \mathrm{L}$ were prepared. According to the developed method and setting the effective parameters based on the optimized condition, the samples were analyzed day to day (6 consecutive days) and in one day $(n=6)$ and the relative recovery $(R R \%)$ values were calculated at the mentioned standard concentrations. The RR\% values in the intra-day (repeatability) and inter-day (reproducibility) situations were in the range of 97.5 to 101.7 and 96.3 to 99.5 percent, respectively.

Also, in order to assess the reproducibility and repeatability, the RSD\% values were calculated using the concentrations ranges of 5, 50, and $150 \mu \mathrm{g} / \mathrm{L}$. The obtained results for RSD $\%$ were in the range of 3.2 to 7.6 percent which confirms the acceptable precision of the developed method. The results of relative recovery (RR \%) and relative standard deviation (RSD\%) have reported in Table 2. 
Table 2. The results of analysis, accuracy and precision of permethrin determination in urine

\begin{tabular}{|c|c|c|c|}
\hline \multirow{2}{*}{ Real sample } & \multirow{2}{*}{ Spiked levels $(\boldsymbol{\mu g} / \mathbf{L})$} & \multicolumn{2}{|c|}{$\mathbf{R R} \pm \mathbf{S D}(\mathbf{\%}),(\mathbf{n}=\mathbf{6})$} \\
\cline { 2 - 4 } & & Intraday & Inter-day \\
\hline \multirow{3}{*}{ Urine } & 0 & N.D. & N.D. \\
\cline { 2 - 4 } & 5 & $97.5 \pm 7.6$ & $96.3 \pm 6.2$ \\
\cline { 2 - 4 } & 50 & $99.1 \pm 6.5$ & $99.5 \pm 5.1$ \\
\cline { 2 - 4 } & 150 & $101.7 \pm 5.1$ & $99.8 \pm 3.2$ \\
\hline
\end{tabular}

*Not detected

Overall, the results achieved in the recovery and precision confirm that the proposed method has concentrated and purified the desired analyte from the complex matrix of the real urine sample with high accuracy and precision and confirms the validity of the method.

\section{Conclusions}

In the present study, the DES-UA-EME technique was successfully developed for the extraction of permethrin from urine samples and subsequent quantification by high-performance liquid chromatography. Different variables affecting the extraction process of this compound were investigated and optimized. Employing a solvent with lower toxicity and volume is an important advantage for a sample preparation method as this developed method possessed and enjoyed such advantages. The obtained results illustrated that, in addition to having better performance and lower volume requirement, the deep eutectic solvent could replace toxic organic solvents in sample preparation methods. Using ultrasonic, the formation of tiny extraction solvent droplets in the sample was remarkably increased; Therefore the contact area (surface) between the analyte and solvent was increased which resulted in a high extraction efficiency and a decrease in extraction time. In comparison to the other sample preparation methods, the proposed technique has the advantages of shorter extraction time, simplicity, and applicability in laboratories with less equipment.

\section{References}

1. Orazbayeva D, Koziel JA, Trujillo-Rodríguez MJ, Anderson JL, Kenessov B. Polymeric ionic liquid sorbent coatings in headspace solid-phase microextraction: A green sample preparation technique for the determination of pesticides in soil. Microchemical Journal 2020. Vol. 157, P. 104996.

2. Su D, Li H, Yan X, Lin Y, Lu G. Biosensors based on fluorescence carbon nanomaterials for detection of pesticides. TrAC Trends in Analytical Chemistry 2020. Vol. 19, P. 116126.

3. Park SK, Lee HJ, Song E, Kim Y, Lee JH, Yoo HJ, Oh JE, Kwon JH. Exposure to permethrin used as a home insecticide: A case study comparing model predictions and excretion of metabolites. Environment International 2021. Vol. 155(1), P. 106581.

4. Viti ML, Mendes KF, dos Reis FC, Guimarães AC, Soria MT, Tornisielo VL. Characterization and metabolism of bound residues of three herbicides in soils amended with sugarcane waste. Sugar Tech 2021. Vol. 23(1), P. 23-37. 
5. Kostopoulou S, Ntatsi G, Arapis G, Aliferis KA. Assessment of the effects of metribuzin, glyphosate, and their mixtures on the metabolism of the model plant Lemna minor L. applying metabolomics. Chemosphere 2020. Vol. 239(1), P. 124582.

6. Zuluaga M, Yathe-G L, Rosero-Moreano M, Taborda-Ocampo G. Multi-residue analysis of pesticides in blood plasma using hollow fiber solvent bar microextraction and gas chromatography with a flame ionization detector. Environmental Toxicology and Pharmacology 2021. Vol. 82(1), P. 103556.

7. Lawrence JF. High-Performance Liquid Chromatography of Pesticides: Analytical Methods for Pesticides and Plant Growth Regulators, Vol. 12. Elsevier; 2016 Apr 20.

8. Nasiri M, Ahmadzadeh H, Amiri A. Sample preparation and extraction methods for pesticides in aquatic environments: A review. TrAC Trends in Analytical Chemistry 2020. Vol. 123(1), P. 115772.

9. Mahara BM, Borossay J, Torkos K. Liquid-liquid extraction for sample preparation prior to gas chromatography and gas chromatography-mass spectrometry determination of herbicide and pesticide compounds. Microchemical journal 1998. Vol. 58(1), P. 31-8.

10. Ferrer C, Gómez MJ, García-Reyes JF, Ferrer I, Thurman EM, Fernández-Alba AR. Determination of pesticide residues in olives and olive oil by matrix solid-phase dispersion followed by gas chromatography/mass spectrometry and liquid chromatography/tandem mass spectrometry. Journal of Chromatography A 2005. Vol. 1069(2), P. 183-94.

11. Poole CF. New trends in solid-phase extraction. TrAC Trends in Analytical Chemistry 2003. Vol. 22(6), P. 362-73.

12. He Y. Recent advances in application of liquid-based micro-extraction: A review. Chemical Papers 2014. Vol. 68(8), P. 995-1007.

13. Pourhossein M, Rahimi Foroushani A, Divani R. Optimization of dispersive liquid liquid microextraction method for determination of trace salivary melatonin using high performance liquid chromatography. Iran Occupational Health 2017. Vol. 14(4), P. 94-85.

14. Pourhossein M, Shahtaheri SJ, Mazloumi A, Rahimi-Foroushani A, Helmi-Kohneshahri M, Khani HM. Dispersive Liquid-Liquid Microextraction for the Determination of Salivary Melatonin as a Biomarker of Circadian Rhythm. Journal of Analytical Chemistry 2018. Vol. 73(10), P. 966-72.

15. Zgoła-Grześkowiak A, Grześkowiak T. Dispersive liquid-liquid microextraction. TrAC Trends in Analytical Chemistry 2011. Vol. 30(9), P. 1382-99.

16. Jordan A, Stoy P, Sneddon HF. Chlorinated Solvents: Their Advantages, Disadvantages, and Alternatives in Organic and Medicinal Chemistry. Chemical Reviews 2020. Vol. 121(3), P. 1582-622.

17. Smith EL, Abbott AP, Ryder KS. Deep eutectic solvents (DESs) and their applications. Chemical reviews 2014. Vol. 114(21), P. 11060-82.

18. Soltanmohammadi F, Jouyban A, Shayanfar A. New aspects of deep eutectic solvents: extraction, pharmaceutical applications, as catalyst and gas capture. Chemical Papers 2021. Vol. 75(2), P. 439-53. 